\title{
SEX RATIOS OF THE WHITE-TAILED ANTELOPE GROUND SQUIRREL (AMMOSPERMOPHILUS LEUCURUS), INDIAN WELLS VALLEY, SAN BERNARDINO COUNTY, CALIFORNIA
}

\author{
Charles J. Randel, III' ${ }^{1}$, and Howard O. Clark, Jr. ${ }^{2}$
}

\begin{abstract}
Aвstract.-We studied the white-tailed antelope ground squirrel during spring and summer 2006 to determine young-of-the-year and adult sex ratios in the Indian Wells Valley, San Bernardino County, California. We calculated a young-of-the-year sex ratio of 1.45:1 (female to male), whereas the adult sex ratio was approximately 1:1. Our young-ofthe-year sex ratio was greater than the 1.1:1 (female to male) natal sex ratio previously reported. Differences between young-of-the-year and adult sex ratios may represent low female young-of-the-year survivorship in the Indian Wells Valley.
\end{abstract}

Key words: white-tailed antelope ground squirrel, Ammospermophilus leucurus, sex ratios, Indian Wells Valley, California.

White-tailed antelope ground squirrels (Ammospermophilus leucurus) are small to medium-sized diurnal ground squirrels distributed throughout western North America (Belk and Smith 1991). Mating typically occurs during the first 2 weeks of March with gestation lasting 30-35 days. Young-of-the-year emerge from the natal burrow as early as mid-May, 1-2 weeks before the end of lactation (Kenagy and Bartholomew 1985). Reported litter size ranges from 5 to 14 (Grinnell and Dixon 1919, Pengelley 1966, Maxwell and Morton 1975, Kenagy and Bartholomew 1985) with birth weights ranging from $2.0 \mathrm{~g}$ (Maxwell and Morton 1975) to $4.0 \mathrm{~g}$ (Pengelley 1966).

Pengelley (1966) reported natal sex ratios of white-tailed antelope ground squirrels as 1.1:1 (all sex ratios will be reported as female to male ratios) based on wild-captured females giving birth in captivity. Hawbecker (1958) studied the congeneric Nelson's antelope ground squirrel (Ammospermophilus nelsoni) in San Benito County, California, and reported an adult sex ratio of 1:1.

Comparatively, adult sex ratios of many Spermophilus species have been reported in the literature as female biased. Verts and Costain (1988) stated that adult sex ratios with strong female bias among Spermophilus species were commonly reported, while juvenile sex ratios frequently did not deviate significantly from 1:1 within the same population. Sex-ratio bias toward females is commonly attributed to greater loss of juvenile males (through predation) as a result of male-biased juvenile dispersal (Ortega 1990). A 4-year study of Spermophilus variegatus yielded a juvenile male-biased sex ratio (1:1.16) with an adult sex ratio close to 1:1 (Oretega 1990). Adult and juvenile sex ratios of Franklin's ground squirrel (Spermophilus franklinii) in Alberta, Canada, were reported as 1:1 (Murie 1973), which is similar to the sex ratio reported for the thirteen-lined ground squirrel (Spermophilus tridecemlineatus; McCarley 1970).

Presently, little information is available on white-tailed antelope ground squirrel youngof-the-year sex ratios. Our study represents the only study of white-tailed antelope ground squirrels in California; previous natural history studies on this species were conducted in Nevada (Bradley 1967, 1968).

This study had 2 objectives. The 1st objective was to determine sex ratios of young-of-theyear and adult white-tailed antelope ground squirrels based on a 1.1:1 female-to-male young-of-the-year ratio reported by Pengelley (1966) and the 1:1 adult ratio reported by Hawbecker (1958). The 2 nd objective was to evaluate how sex ratio of young-of-the-year and adult white-tailed antelope ground squirrels varied temporally in the Indian Wells Valley, San Bernardino County, California.

${ }^{1}$ Sapphos Environmental, Inc., Pasadena, CA 91105. E-mail: crandel@sapphosenvironmental.com

${ }^{2}$ H. T. Harvey \& Associates, Fresno, CA 93711. 
TABle 1. Age and sex class of white-tailed antelope ground squirrel captures, Indian Wells Valley, San Bernardino County, California (21 March-15 July 2006)

\begin{tabular}{|c|c|c|c|c|c|c|c|c|c|}
\hline & \multicolumn{3}{|c|}{ Adult } & \multicolumn{3}{|c|}{ Young of the year } & \multicolumn{3}{|c|}{ Total } \\
\hline & Female & Male & Total & Female & Male & Total & Female & Male & Total \\
\hline Session 1 & 219 & 212 & 431 & 0 & 0 & 0 & 219 & 212 & 431 \\
\hline Session 2 & 218 & 213 & 431 & 167 & 137 & 304 & 385 & 350 & 735 \\
\hline Session 3 & 113 & 113 & 226 & 61 & 20 & 81 & 174 & 133 & 307 \\
\hline Total & 550 & 538 & 795 & 228 & 157 & 385 & 778 & 695 & 1473 \\
\hline
\end{tabular}

Indian Wells Valley is located between the Sierra Nevada and Panamint Mountains, in San Bernardino County, California. Mojave creosote bush scrub and saltbush scrub are the primary plant communities (Holland 1986). The topography of the Indian Wells Valley generally slopes downward from west to east, with dry washes present throughout the region and typically oriented on a north-south axis. Our study was conducted along a 15.3-km length of State Route 178 with the western extent $\left(35^{\circ} 38^{\prime} 33.9^{\prime \prime} \mathrm{N},-117^{\circ} 32^{\prime} 45.3^{\prime \prime} \mathrm{W}\right)$ approximately $16 \mathrm{~km}$ east of Ridgecrest, California, and the eastern extent $\left(35^{\circ} 40^{\prime} 52.7^{\prime \prime} \mathrm{N},-117^{\circ} 23^{\prime} 31.4^{\prime \prime} \mathrm{W}\right)$ $19.3 \mathrm{~km}$ west of Trona, California. Climate of the study area is typical of the Mojave Desert, with low annual precipitation $(12.2 \mathrm{~cm})$ that primarily occurs in winter and spring. Winter precipitation was above average during 2005/ 2006 (17.81 cm; Western Regional Climate Center 2007), the winter prior to our study.

We conducted diurnal rodent trapping in accordance with California Department of Fish and Game's Mohave ground squirrel (Spermophilus mohavensis) survey protocol that stipulates 3 trapping sessions, each consisting of 5 consecutive trapping days (California Department of Fish and Game 2003). The timing of trapping sessions is defined by the California Department of Fish and Game (2003) as follows: session 1, 15 March-30 April; session 2, 1 May-31 May; and session 3, 1 June-15 July. We established 10 trapping grids (hereafter grids) consisting of 100 XLK Sherman live traps (H.B. Sherman Live Traps, Tallahassee, FL) that were baited with 4-way horse feed, placed in a $4 \times 25$ arrangement, and spaced $35 \mathrm{~m}$ apart on center. Each grid surveyed approximately $8.8 \mathrm{ha}$. All grids were opened onehalf hour before sunrise until one-half hour after sunset, with trap checks done no less frequently than every 4 hours, or until ambient air temperature exceeded $32{ }^{\circ} \mathrm{C}$ at $0.3 \mathrm{~m}$ above the surface. While conducting Mohave ground squirrel surveys, we recorded the time, trap location, age, and sex of all individual whitetailed antelope ground squirrels that we captured. All individuals were marked on the venter with a nontoxic Sharpie ${ }^{\circledR}$ permanent marker to prevent repeat counts of previously captured individuals within a session.

We calculated the number of expected individuals for each sex class using the 1.1:1 natal ratio of Pengelley (1966). That is, the number of captured males was multiplied by 1.1 to give the expected number of females in the catch. After determining the expected number of females, we used chi-square analysis to test for sex ratio deviation from 1.1:1.

Our study was based on three 5000-trapday sessions resulting in a total of 15,000 trapdays. We captured 1473 individual white-tailed antelope ground squirrels from 21 March to 15 July 2006 . We captured 431 adults in both session 1 (1.03:1) and session 2 (1.02:1), and 226 adults were captured in session 3 (1:1; Table 1). Adult white-tailed antelope ground squirrel captures were combined for analysis, and we found no difference between our observed adult sex ratio of 1.02:1 and Pengelley's (1996) of $1.1: 1\left(\chi^{2}=3.172, \mathrm{df}=2, P=0.204\right)$.

We captured 385 young-of-the-year whitetailed antelope ground squirrels from 1 May to 15 July 2006. No young-of-the-year squirrels were captured during session 1 , as expected. Session 2 had the largest number of captured young-of-the-year $(n=304)$ for any session and accounted for $79 \%$ of all young-of-the-year captured, with a sex ratio of 1.22:1. We captured 81 young-of-the-year squirrels during session 3 with a sex ratio of 3.35:1. When young-ofthe-year captures from sessions 2 and 3 were combined, we found that males were captured less frequently than expected $\left(\chi^{2}=23.753\right.$, df $=1, P<0.000)$, with the overall young-ofthe-year sex ratio calculated as 1.45:1. 
We found no published documentation of adult white-tailed antelope ground squirrel sex ratios, and we found that our adult sex ratio of approximately 1:1 was similar to the adult sex ratio of Nelson's antelope ground squirrels in San Benito County, California (Hawbecker 1958). Excluding Spermophilus richardsonii (Michener and Michener 1971), our data also supported the previously reported adult sex ratio of 1:1 for congeneric Spermophilus species.

Similarly, we expected young-of-the-year sex ratios to be near the natal sex ratio reported by Pengelley (1966). However, our young-of-the-year female-to-male sex ratio was 1.45:1, representing a $32 \%$ increase in female young-of-the-year compared to Pengelley (1966). Young-of-the-year sex ratios were not reported by Hawbecker (1958).

We recorded an increased female bias in young-of-the-year sex ratios from session 2 to session 3 . We believe much of the variation in trapping data from our study is related to differing survey efforts from session 2 to session 3 . Based on the California Fish and Game (2003) protocol, trapping efforts must terminate when ambient temperatures exceed $32{ }^{\circ} \mathrm{C}$ at $0.3 \mathrm{~m}$ above ground level to prevent mortality due to heat stress. Ambient temperatures typically exceeded $32{ }^{\circ} \mathrm{C}$ between 08:00 and 09:30 during session 3, whereas ambient temperatures during session 2 rarely exceeded $32{ }^{\circ} \mathrm{C}$.

The reported seasonal sex ratio differences in Piute ground squirrels (S. mollis) were attributable to seasonal activity levels (Rickart 1988). Sharpe and Van Horne (1999) found that Piute ground squirrels were most active when temperatures were approximately $25^{\circ} \mathrm{C}$ and bimodal after 15 April when temperatures were greater than $25^{\circ} \mathrm{C}$ (Sharpe and Van Horne 1999). We found no difference in daily activity levels of adult white-tailed antelope ground squirrels at our study site. Differences in youngof-the-year sex ratios in session 3 may indicate that young-of-the-year females are active earlier in the day, or that young-of-the-year males may be less heat tolerant. These alternative explanations are unlikely, as adult males would be expected to exhibit an activity pattern similar to juvenile males, but they do not.

The difference between our data and Pengelley's (1966) data may be attributable to an above-average winter 2005 and spring 2006 precipitation (Western Regional Climate Center 2007). The increased forage from above-aver- age precipitation likely resulted in improved reproductive female body condition. It is likely that improved reproductive body condition of female white-tailed ground squirrels favors increased female natality. However, additional data collection in normal and drought years would be required to determine if female white-tailed antelope ground squirrels are able to skew the sex of offspring due to environmental conditions.

Young-of-the-year dispersal may be a mechanistic explanation for the divergence of youngof-the-year and adult white-tailed ground squirrel sex ratios. Hawbecker (1958) reported no sex-biased difference in dispersal or home range of Nelson's antelope ground squirrel in San Benito County, California. In our study, approximately one-third of all females would have had to disperse from the sampled population to account for differences in young-ofthe-year and adult sex ratios, assuming similar mortality for both females and males. We do not believe that female young-of-the-year dispersal adequately explains differences between adult and young-of-the-year sex ratios.

Nearly $80 \%$ of Nelson's antelope ground squirrels in the San Benito County population were not recaptured in years after initial capture, with relatively low young-of-the-year dispersal of recaptured individuals (Hawbecker 1958). These relatively low recapture rates suggest low annual survival of individual Nelson's antelope ground squirrels. Based on our results, female young-of-the-year white-tailed antelope ground squirrels have lower survival compared to their male counterparts. Hawbecker (1958) reported that male Nelson's antelope ground squirrels were more aggressive in procuring food resources than females, which could be a potential factor in decreased female young-ofthe-year survival in the Indian Wells Valley.

We thank K. Simon and D. Mitchell for assisting with trapping during this study. S.I. Hagen, K.L. Randel, R.A. McCleery, D.B. McNair, and 3 anonymous reviewers provided additional comments and revisions which greatly improved the manuscript. Funding for this study was provided by the California Department of Transportation, District 8.

\section{Literature Cited}

Belk, M.C., AND H.D. SMith. 1991. Ammospermophilus leucurus. Mammalian Species 368:1-8. 
BRADlEY, W.G. 1967. Home range, activity patterns, and ecology of the antelope ground squirrel in southern Nevada. Southwestern Naturalist 12:231-251.

. 1968. Food habits of the antelope ground squirrel in southern Nevada. Journal of Mammalogy 49:14-21.

California Department of Fish and Game. 2003. Mohave ground squirrel survey guidelines. Habitat Conservation Planning Branch, California Department of Fish and Game, Sacramento.

Grinnell, J., AND J. Dixon. 1919. Natural history of the ground squirrels of California. Monthly Bulletin of the State Commission of Horticulture (California) 7:597-709.

Hawbecker, A.C. 1958. Survival and home range in the Nelson antelope ground squirrel. Journal of Mammalogy 39:207-215.

HolLand, R.F. 1986. Preliminary descriptions of the terrestrial natural communities of California. California Department of Fish and Game, Sacramento.

Kenagy, G.J., and G.A. Bartholomew. 1985. Seasonal reproductive patterns in five coexisting California desert rodent species. Ecological Monographs 55: 371-397.

Maxwell, C.S., And M.L. MorTon. 1975. Comparative thermoregulatory capabilities of neonatal ground squirrels. Journal of Mammalogy 56:821-828.

McCarley, H. 1970. Differential reproduction in Spermophilus tridecemlineatus. Southwestern Naturalist 14:293-296.

Michener, D.R., And G.R. Michener. 1971. Sex ratio and interyear residence in a population of Spermophilus richardsonii. Journal of Mammalogy 52:853.
MuRIE, J.O. 1973. Population characteristics and phenology of a Franklin ground squirrel (Spermophilus franklinii) colony in Alberta, Canada. American Midland Naturalist 90:334-340.

Ortega, J.C. 1990. Reproductive biology of the rock squirrel (Spermophilus variegatus) in southeastern Arizona. Journal of Mammalogy 71:448-457.

Pengelley, E.T. 1966. Differential developmental patterns and their adaptive value in various species of the genus Citellus. Growth 30:137-142.

RickarT, E.A. 1988. Population structure of the Piute ground squirrel (Spermophilus mollis). Southwestern Naturalist 33:91-96.

Sharpe, P.B., and B. Van Horne. 1999. Relationships between the thermal environment and activity of Piute ground squirrels (Spermophilus mollis). Journal of Thermal Biology 24:265-278.

Verts, B.J., and D.B. Costain. 1988. Changes in sex ratios of Spermophilus beldingi in Oregon. Journal of Mammalogy 69:186-190.

Western Regional Climate Center. 2007. California climate data: Trona, California [cited 12 November 2007]. Available from: http://www.wrcc.dri.edu/cgibin/cliMONtpre.pl?catron

Received 29 May 2007 Accepted 6 May 2008 